\title{
Sex differences in iron absorption
}

\section{By A. JacoBs, Department of Haematology, University Hospital of Wales, Heath Park, Cardiff $\mathrm{CF}_{4}{ }_{4} \mathrm{XW}$}

The iron content of the body is normally kept constant by a delicate balance between intestinal $\mathrm{Fe}$ absorption and $\mathrm{Fe}$ losses. $\mathrm{Fe}$ is present in all the cells of the body and there is a regular, small, obligatory loss of $\mathrm{Fe}$ due to desquamation from epithelial surfaces. In men the gastrointestinal tract is the major site of such loss and here, in addition to the small amount of $\mathrm{Fe}$ present in epithelial cells and macrophages, there is some loss in the bile and in erythrocytes exuded from the mucosal surface. In the adult up to about I $\mathrm{mg} \mathrm{Fe} / \mathrm{d}$ is lost in this way. In women, menstrual blood loss provides an additional source of $\mathrm{Fe}$ depletion and Hallberg, Hogdahl, Nilsson \& Rybo ( 1966 ) have found an average daily loss of about $0.7 \mathrm{mg}$, with $10 \%$ of women losing in excess of $\mathrm{r} \cdot 4 \mathrm{mg}$. There is no physiological control over the amount of $\mathrm{Fe}$ lost from the body. Balance results from losses determining total body load which in turn influences absorption (Jacobs, 1974).

$\mathrm{Fe}$ is normally obtained from the diet and probably the most important factor affecting the total food Fe absorption is the Fe content of the diet itself. This is usually lower in women than in men (Wretlind, 1970). Next in importance is the release of $\mathrm{Fe}$ from food by the digestive processes and its availability for uptake by the small intestinal mucosa. Fe uptake from the lumen by the epithelial cells of the small intestine is not synonymous with absorption. A variable amount of $\mathrm{Fe}$ is sequestered in the epithelial cell and never reaches the plasma. It is known that the intestinal epithelium rejects unwanted dietary $\mathrm{Fe}$ or transfers increased amounts from the mucosal to the serosal surface, according to the Fe status of the body. The epithelial cells are able to monitor the body's requirements and respond accordingly (Jacobs \& Worwood, 1975).

\section{The availability of food $\mathrm{Fe}$}

The amount of food $\mathrm{Fe}$ available for absorption depends primarily on the amount released in soluble form by the digestive processes. Less than half the total $\mathrm{Fe}$ in food is released by peptic digestion in the stomach and this is largely in the form of ionizable inorganic $\mathrm{Fe}$, except in the instance of meat, where $\mathrm{Fe}$ is released as the haem complex. The amount released is considerably reduced in subjects with gastric atrophy, a factor more commonly found in women. When the stomach contents pass into the jejunum at a $\mathrm{pH}$ approaching neutrality, there are a number of possible chemical interactions. Ferric ions normally undergo increasing polymerization as the $\mathrm{pH}$ rises and finally form a precipitate of ferric hydroxide. Fe 
may also become available due to binding by phytate and phosphate. In the presence of certain dietary chelating agents such as ascorbic acid or fructose, lowmolecular-weight $\mathrm{Fe}$ chelates may be formed which remain soluble at alkaline $\mathrm{pH}$ and are readily available for intestinal uptake. Under normal circumstances, the largest part of the Fe-binding capacity of the gastric contents is provided by the gastric secretions themselves, with the formation of a high-molecular-weight $\mathrm{Fe}-$ mucopolysaccharide complex. Fe is detached from this complex in the lumen of the jejunum and probably enters the intestinal wall as a small complex. Haem $\mathrm{Fe}$ released from food in the stomach appears to enter the intestinal epithelial cell intact. The availability of haem $\mathrm{Fe}$ is uninfluenced by the various intraluminal factors which affect ionizable Fe.

When $\mathrm{Fe}$ absorption from biologically labelled food is measured, there is considerable variation between different foodstuffs. In general, $\mathrm{Fe}$ of animal origin is better absorbed than that of vegetable origin. Some foods, such as eggs, are well known for their inhibitory effect on Fe absorption. It is likely that the influence of particular foodstuffs on Fe absorption is related partly to the presence of chelating agents in their digestive breakdown products. For example, $\mathrm{Fe}$ absorption from veal is inhibited by the presence of corn or black beans, whereas Fe incorporated in corn or black beans is better absorbed when eaten with either veal or fish (Layrisse, Martinez-Torrez \& Roche, 1968). The stimulating effect of fish on $\mathrm{Fe}$ absorption appears to be due to the presence of cysteine in the digestion products of the fish. Similarly, the well-known inhibitory effect of egg on $\mathrm{Fe}$ absorption is related to its content of Fe-binding substances.

\section{The intestinal epithelial cell}

Intraluminal factors in the gastrointestinal tract affect the availability of ionizable $\mathrm{Fe}$ uptake by the epithelial cells but they play no part in the physiological regulation of $\mathrm{Fe}$ absorption. Fe which is destined to pass across the small intestinal mucosa and into the circulating plasma does so very rapidly after its uptake by the epithelial cells. There is a slight lag in the absorption of haem Fe, probably resulting from the necessity for processing by a microsomal haem oxygenase system before the $\mathrm{Fe}$ is released from the haem ring and joins the same metabolic pathway as $\mathrm{Fe}$ which has entered the cell in an ionizable form.

The major mechanism determining the amount of $\mathrm{Fe}$ rapidly transported to the plasma is probably located within the epithelial cell and is extremely sensitive to the Fe status of the body, even in healthy and non-anaemic subjects (Jacobs \& Worwood, 1975). When Fe stores are reduced, $\mathrm{Fe}$ absorption from the intestinal lumen is increased and in $\mathrm{Fe}$ overload, absorption is decreased. Unwanted $\mathrm{Fe}$ which enters the mucosal cell is sequestered there in the form of ferritin and most of this is ultimately lost from the gut wall with the exfoliation of villous cells at the end of their normal lifespan.

The control of absorption has been studied at cellular level in the rat (Jacobs \& Worwood, 1975). The $\mathrm{Fe}$ content of intestinal epithelial cells is reduced in $\mathrm{Fe}$ deficiency, though it is not affected by Fe loading. The greatest concentration of $\mathrm{Fe}$ 


\section{Vol. 35 Sex differences in response to nutritional variables}

is found in the mitochondria. In the Fe-deficient state, not only is there a reduction in cytosol $\mathrm{Fe}$, but a considerable reduction both in mitochondrial $\mathrm{Fe}$ content and in the activity of mitochondrial haem enzymes. When $\left[{ }^{39} \mathrm{Fe}\right]$ transferrin is injected intravenously, there is a rapid uptake of $\mathrm{Fe}$ by the intestinal epithelial cells and this is concentrated mainly in the mitochondria. This occurs more rapidly and to a greater extent in Fe-deficient animals. Mitochondria appear to be not only the site of highest $\mathrm{Fe}$ concentration in the epithelial cells but also the major destination of $\mathrm{Fe}$ entering cells from the plasma. In Fe deficiency, where the mitochondria are $\mathrm{Fe}-$ depleted, and there is a low activity of Fe-containing enzymes, a high proportion of the Fe derived from the plasma enters this organelle. When Fe uptake from the mucosal surface of the cell is measured, it is, again, the Fe-deficient cells which are most avid (Howard \& Jacobs, 1972). Fe taken up from the lumen is found first associated with a soluble, non-ferritin fraction of the cytosol, probably a transferrin-like protein, and from here it is either transferred across the serosal surface of the cell or incorporated into ferritin. The pathway of Fe absorption therefore appears to involve the cell sap and not the mitochondria, though some early uptake of $\mathrm{Fe}$ by the mitochondria can be demonstrated, particularly in Fedepleted cells.

\section{The control of Fe absorption}

All the cells of the body require $\mathrm{Fe}$ for the synthesis of Fe-containing proteins and this is obtained from extracellular transferrin. The developing intestinal epithelial cell and the mature cell, during its non-absorptive phase, obtain their $\mathrm{Fe}$ in the same fashion. Fe is taken up by the cell, first into a labile pool and then into cellular proteins, primarily during the synthesis of cytochromes and non-haem $\mathrm{Fe}$ proteins in the mitochondria. If an adequate supply of $\mathrm{Fe}$ is available, the concentration of labile $\mathrm{Fe}$ in the cell sap will be great enough to stimulate apoferritin synthesis and some of the incoming $\mathrm{Fe}$ will be incorporated into ferritin. In the special instance of the intestinal epithelial cell, uptake from the lumen will depend not only on the metabolic requirements of the cell but also on the amount of $\mathrm{Fe}$ presented. The bipolar anatomy of the cell enables $\mathrm{Fe}$ which enters to be transferred to the interior of the body. When Fe requirements of the cell are relatively low and where the body's requirements are normal, Fe uptake into the cells will be low. In Fe deficiency, little Fe is available within the body for epithelial cells and these cells are therefore Fe-depleted. Mitochondrial requirements for $\mathrm{Fe}$ enzyme synthesis are increased for as along as mitochondrial needs are unsatisfied. This results in an increased uptake of Fe from the lumen of the intestine into the carrier pool. The increased requirements of the body result in a rapid transfer of $\mathrm{Fe}$ from the labile pool to the plasma. The concentration of $\mathrm{Fe}$ in the labile pool does not reach a level sufficient to stimulate apoferritin synthesis. The body's need for Fe is reflected in the epithelial cell's need for Fe and this is the major factor controlling passage of $\mathrm{Fe}$ from the lumen into the cell.

The delivery of $\mathrm{Fe}$ from the intestinal epithelial cell to the plasma is poorly understood. In the Fe-loaded rat described by Worwood \& Jacobs (1972) there 
were almost normal values for serum Fe concentration, total Fe-binding capacity and mucosal $\mathrm{Fe}$ content, though $\mathrm{Fe}$ absorption was only one-third of the normal value. This suggests that high concentrations of $\mathrm{Fe}$ in the liver (and other storage organs) could regulate $\mathrm{Fe}$ absorption independently of changes in the plasma $\mathrm{Fe}$ concentration and delivery to the epithelial cells. In human subjects with low $\mathrm{Fe}$ stores, there is an increase in absorption even when plasma Fe concentration and transferrin saturation is normal (and presumably epithelial $\mathrm{Fe}$ status is also normal). When the concentration of circulating ferritin is used as an index of $\mathrm{Fe}$ stores, there is a negative correlation between stores and Fe absorption in otherwise healthy subjects (Walters, Jacobs, Worwood, Trevett \& Thompson, 1975). Cavill, Worwood \& Jacobs (1975) have suggested that serosal transfer of $\mathrm{Fe}$ may be regarded simply as part of an equilibrium between plasma $\mathrm{Fe}$ and the 'exchangeable' $\mathrm{Fe}$ in all tissues. The total 'exchangeable' $\mathrm{Fe}$ in the body largely reflects the level of storage $\mathrm{Fe}$, though a small part is derived from the labile pool in the intestinal cells. If plasma Fe turnover remains constant, then any decrease in storage $\mathrm{Fe}$ must be balanced by an increased transfer from intestine to plasma to maintain the equilibrium.

Recent work on the precise mechanism whereby the delicate regulation of $\mathrm{Fe}$ absorption maintains total body Fe balance has served only to confirm the view put forward by McCance \& Widdowson (1936) that absorption is indeed the ultimate physiological mechanism for the control of body Fe load. In normal individuals the body $\mathrm{Fe}$ stores are the most important factor influencing absorption and these are lower in women than in men. The higher $\mathrm{Fe}$ absorption found in women is a reflection of this and results from their greater Fe losses.

\section{REFERENCES}

Cavill, I., Worwood, M. \& Jacobs, A. (1975). Nature, Lond. 256, 328.

Hallberg, L., Hogdahl, A.-M., Nilsson, L. \& Rybo, G. (1966). Acta obstet. gynec. scand. 45, 25. Howard, J. \& Jacobs, A. (I972). Br. f. Haemat. 23, 595.

Jacobs, A. (1974). In Iron in Biochemistry and Medicine [A. Jacobs and M. Worwood, editors]. London: Academic Press.

Jacobs, A. \& Worwood, M. (1975). Br. f. Haemat. 31 (Suppl.), 89.

Layrisse, M., Martinez-Torres, C. \& Roche, M. (1968). Am. F. clin. Nutr. $21,1175$.

McCance, R. A. \& Widdowson, E. M. (1937). Lancet ii, 680.

Walters, G. O., Jacobs, A., Worwood, M., Trevett, D. \& Thompson, W. (1975). Gut 16, 188.

Worwood, M. \& Jacobs, A. (1972). Br. F. Haemat. 22, 265.

Wretlind, A. (1970). In Iron Deficiency [L. Hallberg, H.-G. Harwerth and A. Vannotti, editors]. London: Academic Press. 